\title{
RENAL OXYGEN CONSUMPTION IN MAN DURING ABDOMINAL COMPRESSION
}

\author{
By STANLEY E. BRADLEY ${ }^{1}$ AND MEYER H. HALPERIN \\ (From the Evans Memorial, Massachusetts Memorial Hospitals, and the Department of \\ Medicine, Boston University School of Medicine, Boston)
}

(Received for publication March 18, 1948)

The renal blood flow, glomerular filtration rate and maximal rates of glucose reabsorption and diedrast excretion are greatly reduced in man by increased intra-abdominal pressure (1). These effects may be attributed to simultaneous elevations in renal venous pressure and intra-pelvic pressure which act respectively to decrease blood flow and to halt urine flow from nephrons which have relatively low terminal intra-luminal pressures. Thus a large proportion of the renal parenchyma apparently no longer functions in producing urine. It seemed of interest to determine whether renal oxygen consumption is altered under these conditions.

\section{METHODS}

Eleven convalescent patients, ranging in age from 18 to 36 years, five males and six females, were studied in the resting basal state. In five subjects, renal blood flow and renal oxygen consumption were determined before, during, and following compression of the abdomen by a pneumatic girdle inflated at $80 \mathrm{~mm}$. $\mathrm{Hg}$. In the remainder, only the renal venous oxygen concentrations were obtained under the same conditions.

Determination of renal blood flow. Renal blood flow was estimated as the sodium p-aminohippurate $(\mathrm{PAH})^{2}$ clearance corrected by the value for renal extraction of PAH. The techniques described at length by Goldring and Chasis (2) were employed in the determination of PAH clearances. Urine was collected by catheterization and the bladder washed out with isotonic saline solution during two or more 10 - to 15 -minute periods before, during, and after compression. Blood samples were collected from a peripheral vein or artery at approximately 30-minute intervals and the values used in the calculation of clearances were determined by interpolation. Aliquots of appropriately diluted urine samples and plasma filtrates, prepared by the method of Fujita and Iwatake (3), were analyzed for PAH by the method of Smith and his co-workers (4).

\footnotetext{
1 Present address: Department of Medicine, Columbia University College of Physicians and Surgeons, New York City.

2 Sodium p-aminohippurate was supplied in ampules of 20 per cent sterile, pyrogen-free solution, through the courtesy of Sharp and Dohme, Inc., Glenolden, Pennsylvania.
}

Renal venous blood was sampled by the method of venous catheterization for the purpose of determining PAH extraction. An extra-length radio-opaque ${ }^{3}$ ureteral catheter, washed out constantly with a slow infusion of sterile isotonic saline solution to prevent blockage by clotting, was introduced into a median basilic vein under local anesthesia. It was passed under fluoroscopic control through the superior vena cava and the right atrium into the inferior vena cava. Here the curved tip (Cournand tip) of the catheter was directed to the right and passed into the right renal vein. In the proper position, it could be visualized in the right side of the abdominal cavity, caudad to the shadow of the liver. The right renal vein was always used as a source of renal venous blood because the left spermatic or ovarian vein introduces a relatively large quantity of non-renal venous blood into the left renal vein. Renal extraction of PAH was determined as the difference in PAH concentration in the renal venous and peripheral arterial or venous blood divided by the concentration in peripheral blood.

The concentration of $\mathrm{PAH}$ in renal venous blood was measured after a known amount of standard had been added to the plasma filtrate. This procedure improves recovery from plasma of $\mathrm{PAH}$ when present in low concentration. No evidence of movement of $\mathrm{PAH}$ into or out of erythrocytes was noted even when the plasma and cells remained mixed for several hours after sampling.

Hematocrits of peripheral arterial and renal venous blood were determined in duplicate on blood sampled for oxygen content, using Wintrobe tubes centrifuged at 3000 r.p.m. for one hour. Hematocrit values were corrected by a factor of 0.915 to allow for an error of 8.5 per cent due to the trapping of plasma between cells during centrifugation (5). The average arterial hematocrit was employed in calculating the volume of whole blood flowing through the kidney.

Renal blood flow was calculated from these values as follows :

$$
R B F=\frac{U V}{P} \times \frac{1}{1-H c t} \times \frac{1}{E}
$$

where $R B F$ is the renal blood flow in $\mathrm{ml}$. per minute; $U$, the urinary, and $P$, the arterial plasma concentration of $\mathrm{PAH}$ in $\mathrm{mgm}$. per cent; $V$, the volume of urine formed in $\mathrm{ml}$. per minute; Hct, the average arterial hematocrit; and $E$, the renal extraction of $\mathrm{PAH}$, in per cent.

Determination of renal oxygen consumption. Values of renal venous and peripheral arterial oxygen concen-

3 This catheter is manufactured by the United States Catheter and Instrument Company, Glens Falls, New York. 
trations were obtained as close as possible to the midpoint of the urine collection period preceding the application of pressure, at the midpoint of the period of compression, and within 30 minutes after the pressure was released. These figures were used in calculating oxygen consumption of the kidney on the basis of averaged renal blood flow during each of the three phases.

The blood samples for oxygen determination were collected anaerobically in oiled, heparinized syringes, and stored under mercury in a refrigerator. The analyses were carried out within several hours. No measurable change in concentration occurred during this period.

Oxygen was determined in $1.0-\mathrm{ml}$. samples by the method of Van Slyke and Neill (6). Duplicate analyses agreed within 0.1 volume per cent. In order to eliminate variations in observed oxygen content due to changes in hematocrits as a result of dilution during sampling or during passage through the kidney, rather than to changes in oxygen extraction, all values were corrected to a constant hematocrit level, as follows:

$$
\text { corrected oxygen content }=\mathrm{O}_{2} \times \frac{H c t_{A}}{H c t}
$$

where $\mathrm{O}_{2}$ is the observed oxygen content of the blood sample; $H c t$ its hematocrit; and $\mathrm{Hct}_{\Delta}$ the average arterial hematocrit. This correction was small, usually amounting to less than one per cent of the oxygen content.

The difference between the corrected values of oxygen content of peripheral arterial and renal venous blood in volumes per cent was multiplied by the renal blood flow in hundreds of milliliters per minute to obtain the renal oxygen consumption in milliliters per minute.

In six subjects renal venous oxygen contents alone were measured before, during, and after compression.
These figures have not been corrected by hematocrit values.

\section{RESULTS}

The renal blood flow always fell during compression and returned to the control level after release of pressure (Table I). The renal extraction of PAH remained relatively constant. It is possible that the decrements in extraction during "recovery" in J. B. and B. E. resulted from displacement of the catheter by the experimental procedure with contamination of the sample by blood from the inferior vena cava. Since there was greater difficulty keeping the catheter in place in J. B. than in any of the other subjects, the findings in J. B. are particularly suspect.

The renal arteriovenous oxygen difference was not altered in any consistent manner by compression, remaining relatively constant in J. S., B. E., and F. S., falling in M. T. and rising in J. B. (Table I). Further studies of renal venous oxygen content in six other subjects (Table II) likewise failed to reveal any consistent or statistically significant change. Though the technical difficulties mentioned above may have influenced the results in J. B., accounting for the depression in renal venous oxygen content and the elevation in renal arteriovenous oxygen difference, it is

TABLE I

Renal oxygen consumption during abdominal compression

\begin{tabular}{|c|c|c|c|c|c|c|c|c|c|}
\hline \multirow[t]{2}{*}{ Subject } & \multirow{2}{*}{$\begin{array}{c}\text { Renal } \\
\text { extraction } \\
\text { of PAH }\end{array}$} & \multicolumn{2}{|c|}{ Oxygen content } & \multirow[t]{2}{*}{ A-V } & \multirow{2}{*}{\multicolumn{2}{|c|}{ Renal blood flow }} & \multirow{2}{*}{\multicolumn{2}{|c|}{ Renal oxygen consumption }} & \multirow{3}{*}{$\begin{array}{l}\text { Procedure } \\
\\
\begin{array}{l}\text { Control } \\
\text { Pressure } \\
\text { Recovery }\end{array}\end{array}$} \\
\hline & & Arterial & Venous & & & & & & \\
\hline J. B. & $\begin{array}{c}\text { per cent } \\
89.8 \\
89.0 \\
83.5\end{array}$ & \begin{tabular}{|c|} 
vols. per cent \\
15.2 \\
15.1 \\
14.9
\end{tabular} & $\begin{array}{c}\text { ools. per cent } \\
14.5 \\
13.1 \\
14.2\end{array}$ & $\begin{array}{c}\text { vols. per cent } \\
0.6 \\
2.0 \\
0.7\end{array}$ & $\begin{array}{c}\begin{array}{c}\text { ml. per } \\
\text { minute }\end{array} \\
925 \\
502 \\
790\end{array}$ & $\begin{array}{c}\begin{array}{c}\text { per cent } \\
\text { change }\end{array} \\
-46\end{array}$ & $\begin{array}{c}\text { ml. per } \\
\text { minute } \\
6.0 \\
10.2 \\
5.6\end{array}$ & $\begin{array}{c}\begin{array}{c}\text { per cent } \\
\text { change }\end{array} \\
+69\end{array}$ & \\
\hline M. T. & $\begin{array}{l}92.5 \\
94.6 \\
96.0\end{array}$ & $\begin{array}{l}14.5 \\
14.3 \\
14.5\end{array}$ & $\begin{array}{l}13.6 \\
13.8 \\
13.4\end{array}$ & $\begin{array}{l}0.9 \\
0.5 \\
1.0\end{array}$ & $\begin{array}{l}849 \\
229 \\
928\end{array}$ & -73 & $\begin{array}{l}7.6 \\
1.2 \\
9.7\end{array}$ & -84 & $\begin{array}{l}\text { Control } \\
\text { Pressure } \\
\text { Recovery }\end{array}$ \\
\hline J.S. & $\begin{array}{l}92.2 \\
99.0 \\
96.4\end{array}$ & $\begin{array}{l}18.0 \\
18.3 \\
18.3\end{array}$ & $\begin{array}{l}17.1 \\
17.4 \\
17.2\end{array}$ & $\begin{array}{l}0.9 \\
0.8 \\
1.1\end{array}$ & $\begin{array}{r}1115 \\
425 \\
1156\end{array}$ & -62 & $\begin{array}{r}10.4 \\
3.6 \\
13.3\end{array}$ & -65 & $\begin{array}{l}\text { Control } \\
\text { Pressure } \\
\text { Recovery }\end{array}$ \\
\hline B. E. & $\begin{array}{l}95.7 \\
94.8 \\
90.8\end{array}$ & $\begin{array}{l}16.1 \\
15.9 \\
16.3\end{array}$ & $\begin{array}{l}14.5 \\
14.5 \\
14.7\end{array}$ & $\begin{array}{l}1.6 \\
1.4 \\
1.5\end{array}$ & $\begin{array}{l}815 \\
640 \\
956\end{array}$ & -21 & $\begin{array}{r}13.0 \\
9.3 \\
14.8\end{array}$ & -29 & $\begin{array}{l}\text { Control } \\
\text { Pressure } \\
\text { Recovery }\end{array}$ \\
\hline F. S. & $\begin{array}{l}88.0 \\
87.5 \\
90.7\end{array}$ & $\begin{array}{l}15.3 \\
15.3 \\
*\end{array}$ & $\begin{array}{l}13.9 \\
13.9 \\
*\end{array}$ & $\begin{array}{l}1.4 \\
1.5\end{array}$ & $\begin{array}{r}1025 \\
418 \\
*\end{array}$ & -59 & $\begin{array}{r}14.2 \\
6.2\end{array}$ & -56 & $\begin{array}{l}\text { Control } \\
\text { Pressure } \\
\text { Recovery }\end{array}$ \\
\hline
\end{tabular}

* These values were not obtained because of technical difficulties. 
TABLE II

Renal venous oxygen content during abdominal compression

\begin{tabular}{|c|c|c|c|}
\hline \multirow{2}{*}{ Subject } & \multicolumn{3}{|c|}{$\begin{array}{l}\text { Renal venous oxygen content } \\
\text { ml. per cent }\end{array}$} \\
\hline & Control & Pressure & Recovery \\
\hline $\begin{array}{l}\text { W. F. } \\
\text { E. R. } \\
\text { J. D. } \\
\text { F. M. } \\
\text { L. J. } \\
\text { G. C. }\end{array}$ & $\begin{array}{l}14.5 \\
13.9 \\
19.5 \\
17.2 \\
16.9 \\
13.9\end{array}$ & $\begin{array}{l}14.5 \\
14.3 \\
19.8 \\
17.1 \\
17.7 \\
14.3\end{array}$ & $\begin{array}{l}14.4 \\
19.6 \\
17.4 \\
16.9 \\
14.4\end{array}$ \\
\hline
\end{tabular}

impossible to demonstrate conclusively that the pattern of behavior in J. B. differs significantly from that of the other members of the series. For this reason, elimination of J. B. from consideration was deemed inadmissible.

The consumption of oxygen by the kidneys averaged $10.3 \mathrm{ml}$. per minute in the control resting state, ranging from $6.0 \mathrm{ml}$. per minute to 14.2 ml. per minute. With compression it fell to 6.1 ml. per minute on the average, a reduction of 41 per cent. At the same time, the renal blood flow was reduced on the average by 52 per cent. This parallel reduction in renal blood flow and renal oxygen consumption occurred in every subject except J. B. Following release of the pressure all values returned to, or close to, the initial figures.

In association with these changes, the urine flow decreased sharply and the urinary concentration of $\mathrm{PAH}$ rose.

\section{DISCUSSION}

The renal oxygen consumption is generally believed to be chiefly a function of the blood flow through the kidney $(7,8)$. Van Slyke and his co-workers (7) found this relationship in normal unoperated dogs over a wide range of blood flow and in common with other workers $(9,10)$, failed to observe any change referable to alterations in the rate of urine formation. However, the importance of renal arterial pressure changes have been emphasized by Kramer and Winton (11). In a study of oxygen consumption by the explanted canine kidney, these investigators found that alterations in the perfusion pressure produced more or less equivalent changes in oxygen uptake. When blood flow varied spontaneously, independently of perfusion pressure, renal oxygen consumption was not altered.

There is no reason to believe that the renal arterial pressure is affected by abdominal compression at $80 \mathrm{~mm}$. $\mathrm{Hg}$ since intra-abdominal pressure rises no more than $20 \mathrm{~mm}$. $\mathrm{Hg}$, well below the diastolic pressure in the renal artery (1). In addition, it is probable that vasomotor changes are not concerned in the reduction of renal blood flow, although the available facts may be interpreted as evidence of total ischemia in part of the renal vascular bed with "functional amputation" of a portion of renal parenchyma. In this view, the proportionate reduction in oxygen consumption, blood flow, filtration rate and maximal tubular capacities would result from excluding from perfusion a certain fraction of functional renal tissue. However, it has been pointed out elsewhere (1) that this hypothesis requires simultaneous vasodilatation and vasoconstriction in the kidney, and may be set aside as unlikely. Thus it seems permissible to consider oxygen consumption in terms of the kidney as a whole, dismissing the possibility that perfusion pressure may be important in this situation.

The relationship between renal blood flow and oxygen consumption observed by Van Slyke and others in the dog, appears in these data obtained in man. It is possible that this association arises from the diminished delivery of oxygen to the kidney with subsequent reduction of the activity of oxidative enzyme systems in tubular cells. These systems have been found to be extremely sensitive to environmental oxygen tension (12), responding to slight changes by marked reduction in activity. However, the oxygen content of renal venous blood does not change significantly during abdominal compression and it seems unlikely that there is any change in the oxygen tension of renal interstitial fluids. It is interesting that reduced oxygen consumption during abdominal compression is associated with apparent cessation of urine formation in a certain proportion of nephrons (1). The possibility that renal oxygen consumption depends upon the relative proportion of tubular tissue actively functioning in the formation of urine from glomerular filtrate cannot be excluded as an explanation of the data presented here. 


\section{SUMMARY}

The renal oxygen consumption has been measured directly in normal resting human subjects before, during, and after abdominal compression at $80 \mathrm{~mm} . \mathrm{Hg}$.

Resting control oxygen consumption averaged $10.3 \mathrm{ml}$. per minute in five subjects, ranging from $6.0 \mathrm{ml}$. per minute to $14.2 \mathrm{ml}$. per minute.

Abdominal compression reduced renal oxygen consumption to $6.1 \mathrm{ml}$. per minute on the average, or by 41 per cent. At the same time the renal blood flow was reduced, on the average by 52 per cent. There was no significant change in renal venous oxygen content.

\section{ACKNOWLEDGMENT}

We wish to express our appreciation to Misses Irene Goos, Elizabeth Nolan, and Constance Qua for technical assistance, and to Dr. John Fertig for aid and advice in evaluating the data statistically.

\section{BIBLIOGRAPHY}

1. Bradley, S. E., and Bradley, G. P., The effect of increased intra-abdominal pressure on renal function in man. J. Clin. Invest., 1947, 26, 1010.

2. Goldring, W., and Chasis, H., Hypertension and Hypertensive Disease. The Commonwealth Fund, New York, 1944, 353 pp.

3. Fujita, A., and Iwatake, D., Bestimmung des echten
Blutzuckers ohne Hefe. Biochem. Ztschr., 1931, 242, 43.

4. Smith, H. W., Finkelstein, N., Aliminosa, L., Crawford, B., and Graber, M., The renal clearances of substituted hippuric acid derivatives and other aromatic acids in dog and man. J. Clin. Invest., 1945, 24, 388.

5. Chapin, M. A., and Ross, J. F., The determination of the true cell volume by dye dilution, by protein dilution, and with radioactive iron. The error of the centrifuge hematocrit. Am. J. Physiol., 1942, 137, 447.

6. Van Slyke, D. D., and Neill, J. M., The determination of gases in blood and other solutions by vacuum extraction and manometric measurement. I. J. Biol. Chem., 1924, 61, 523.

7. Van Slyke, D. D., Rhoads, C. P., Hiller, A., and Alving, A. S., Relationships between urea excretion, renal blood flow, renal oxygen consumption, and diuresis. The mechanism of urea excretion. Am. J. Physiol., 1934, 109, 336.

8. Smith, H. W., The Physiology of the Kidney. Oxford University Press, New York, 1937, 310 pp.

9. Hayman, J. M., Jr., and Schmidt, C. F., The gaseous metabolism of the dog's kidney. Am. J. Physiol., 1928, 83, 502.

10. Fee, A. R., A note on the effect of sodium sulphate on the oxygen usage of the kidney. J. Physiol., $1929,67,14$.

11. Kramer, K., and Winton, F. R., The influence of urea and of change in arterial pressure on the oxygen consumption of the isolated kidney of the dog. J. Physiol., 1939, 96, 87.

12. Green, D. E., Personal communication. 